\title{
Calm and Frenzy: marine obligate hydrocarbonoclastic bacteria sustain ocean wellness Michail M Yakimov ${ }^{1}$, Rafael Bargiela ${ }^{2}$ and Peter N Golyshin ${ }^{2}$
}

According to current estimates, the annual volume of crude oil entering the ocean due to both anthropogenic activities and naturally occurring seepages reaches approximately 8.3 million metric tons. Huge discharges from accidents have caused large-scale environmental disasters with extensive damage to the marine ecosystem. The natural clean-up of petroleum spills in marine environments is carried out primarily by naturally occurring obligate hydrocarbonoclastic bacteria (OHCB). The natural hosts of OHCB include a range of marine primary producers, unicellular photosynthetic eukaryotes and cyanobacteria, which have been documented as both, suppliers of hydrocarbon-like compounds that fuel the 'cryptic' hydrocarbon cycle and as a source of isolation of new OHCB. A very new body of evidence suggests that $\mathrm{OHCB}$ are not only the active early stage colonizers of plastics and hence the important component of the ocean's 'plastisphere' but also encode an array of enzymes experimentally proven to act on petrochemical and bio-based polymers.

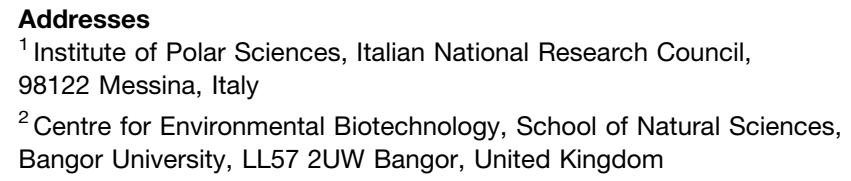

${ }^{2}$ Centre for Environmental Biotechnology, School of Natural Sciences, Bangor University, LL57 2UW Bangor, United Kingdom

Corresponding author: Yakimov, Michail M (mikhail.iakimov@cnr.it)

Current Opinion in Biotechnology 2021, 73:337-345

This review comes from a themed issue on Environmental biotechnology

Edited by Luigi Vezzulli and Marco Ventura

https://doi.org/10.1016/j.copbio.2021.09.015

0958-1669/৫ 2021 Elsevier Ltd. All rights reserved.

\section{Introduction and updated taxonomical overview on marine OHCB}

Some 15 years ago we reported on an ecophysiologically unusual group of marine microorganisms, termed 'obligate hydrocarbonoclastic (oil-degrading) bacteria (OHCB) $\left[1^{\bullet \bullet}\right]$. One of their most distinct metabolic peculiarities is their ability for utilizing almost exclusively hydrocarbons as a sole source of energy and carbon (a metabolic trait, called the 'OHCB paradigm' $\left[1^{\bullet \bullet}\right]$ ). Here, we need to note that genetic loci of this physiological trait are relatively easily transmissible between bacteria, which is known for decades, for example, for alkane hydroxylases/monooxygenases and P450 (CYP153) cytochromes [2] or for a half-century, aromatic monooxygenases [3]. Importantly, the phylogenies of these enzymes are uncoupled with the taxonomic placement of producing organisms [4] therefore the term OHCB is strain-specific and cannot be attributed to a higher taxon.

The ecological importance of OHCB in the biological removal of petroleum hydrocarbons from various polluted marine environments around the world has currently been evidenced during last dramatic oil spill disasters, such as aforementioned blowout of the Deepwater Horizon (DWH) oil rig (see references below). Since the discovery of the first obligate marine hydrocarbonoclastic bacteria being as only members of the class Gammaproteobacteria, their taxonomic diversity has not much been changed at the level of higher taxa. To date, of the eleven recognized genera accommodating the OHCB species, only the genus Planomicrobium includes the species previously known as Planococcus alkanoclasticus [5], order Firmicutes within the class Bacilli, has been added to the list. The rest of the well-established and novel OHCBs are the members of the class Gammaproteobacteria and are subdivided into four orders: Cellvibrionales (Porticoccus $\left[6^{\circ}\right]$ ); Nevskiales (Algiphilus $\left[7^{\circ}\right]$ and Polycyclovorans [8]); Oceanospirillales (Alcanivorax [9], Neptunomonas [10], Oleibacter [11], Oleiphilus [12], Oleispira [13] and Thalassolituus [14]) and Thiothrichales (Cycloclasticus [15]).

Initially characterized as highly specialized hydrocarbonoclastic bacteria that degrade either aliphatic (Alcanivorax, Oleibacter, Oleiphilus, Oleispira, Thalassolituus) or aromatic (Cycloclasticus, Neptunomonas) hydrocarbons $\left[1^{\bullet \bullet}, 16-18\right]$, OHCB possess a higher metabolic versatility than previously assumed. For example, in addition to the type species of the genus, Alcanivorax borkumensis $\mathrm{SK} 2^{\mathrm{T}}$, the genus Alcanivorax, currently includes 14 further species with validly published names (https://lpsn.dsmz.de/ genus/alcanivorax), some of which exhibit genome sizes much larger than that in the strain SK2 ${ }^{\mathrm{T}}$ and, in turn, utilize a larger range of growth substrates. More specifically, some Alcanivorax strains were found to be able to degrade simple sugars such as arabinose and glucose [19] and simple aromatic compounds, such as benzene, chlorobenzene, toluene [20] expanding the metabolic capability of this group of organisms, historically known as narrow specialists in degradation of aliphatic, branched hydrocarbons (including isoprenoids) and cycloalkanes 
$\left[1^{\bullet \bullet}, 9\right]$. In concordance, some mussel and sponge symbionts isolated from deep-sea gas and oil seeps [21] were classified as the members of the genus Cycloclasticus, the genus of well-established primarily degraders of (poly) aromatic hydrocarbons in marine environments. They were found to be similar to free-living Cycloclasticus that bloomed during the DWH oil spill [22-27 and references therein]. Both these groups of bacteria were capable of degradation of short-chain alkanes ethane, propane and butane $[21,22]$, thus highlighting the expanded role of these keystone species in the degradation of hydrocarbons released into marine environment. Of special attention are the recently uncovered novel OHCBs (Algiphilus aromaticivorans, Polycyclovorans algicola, Porticoccus hydrocarbonoclasticus) that represent novel genera and species and that were isolated from eukaryotic phytoplankton $\left[6^{\bullet}, 7^{\bullet}, 8^{\circ}\right]$. All these isolates can use wide range of hydrocarbons, from aliphatic $\left(\mathrm{C}_{10}-\mathrm{C}_{16}\right)$ and branched (phytane, pristane) to mono-aromatic (benzene, toluene, $p$-xylene) and poly-aromatic hydrocarbons (naphthalene, anthracene, phenanthrene, pyrene, fluorene) as sole carbon sources for growth $[17,18]$.

\section{Marine OHCBs and the phycosphere}

Marine $\mathrm{OHCBs}$ appear to be confined to the marine environment, where they tend to be highly enriched in petroleum-contaminated areas. However, in addition to polluted sites, these organisms have been found in shallow, coastal and deep pristine areas around the world including polar regions, where no apparent hydrocarbon pollution has ever been recorded (Figure 1).

As highlighted in recent reviews, there are several biotic as well as abiotic sources from which hydrocarbons, albeit in small quantities, can enter the ocean and sustain the emergence of OHCBs in both pristine and remote areas $[16,29]$. One of the ubiquitous sources of biotic hydrocarbons is chlorophyll $A$, the central pigment of photosynthesis, which is an aromatic porphyrin ring with side chain of diterpene hydrocarbon (phytol) and is accounting for $0.3 \%-5 \%$ of the dry weight of microalgal and cyanobacterial cell [26]. It should be noted that, as it has been known for a long time, many microalgae and especially cyanobacteria are capable of producing significant quantities of various types of hydrocarbons, including longchain alkanes $\left[30,31^{\bullet \bullet}, 32^{\bullet}, 33,34^{\bullet}\right]$, with estimated global flux of de-novo produced hydrocarbons exceeding fossil petroleum inputs into ocean by $100-500$-fold $\left[35^{\bullet \bullet}, 36\right]$. Therefore, it does not seem accidental that representatives of Alcanivorax, Thalassospira, Oleibacter as well as new genera and species of OHCBs (Polycyclovorans, Algiphilus and $P$. hydrocarbonoclasticus) have been commonly reported to be associated with many species of phytoplankton (diatoms, dinoflagellates, coccolithophores) [16,29,37-41]. In this regard, the global distribution of OHCBs in the oceans can be explained by their conquest of still poorly studied and underexploited biotopes - the cell surface, or phycosphere [29], of marine phytoplankton. The association of some OHCB taxa with these primary producers raises important questions regarding their ecology and their contribution to ocean wellness. Oil pollution and biogenic production of hydrocarbons by phytoplankton are corresponding aspects of the long-term and short-term hydrocarbon cycles in the oceans, in which OHCB communities, both phycosphere-associated and free-living in seawater environments, play a significant role.

\section{Marine OHCBs and the plastisphere}

In addition to being very important for the sustainability of ocean ecosystems on a planetary scale in respect to the hydrocarbon degradation, OHCB appear to play an additional and yet underestimated role as an important part of the marine 'plastisphere', the newly recognized microbial assemblages colonizing and modifying plastics released in the ocean $\left[42,43,44^{\bullet}, 45-47\right]$. Petroleum-derived synthetic plastics, including low-density and high-density polyethylene (LDPE and HDPE), polystyrene (PS), polypropylene (PP), polyvinyl chloride (PVG), polyurethane (PUR), and polyethylene terephthalate (PET), are currently major pollutants of marine environments across the globe. It has recently been estimated that between 4.8 and 12.7 million Metric Tons (MTs) of plastic have entered the ocean annually over the past decade, largely due to improper land-based waste management [48]. According to the Plastics-Europe, the global yield of plastics reached 348 million MTs in 2018 [49]. Without major interventions in waste generation and recycling, it was predicted that by 2025, the cumulative amount of mismanaged plastic wastes entering the ocean could reach almost 250 million MTs $[48,50]$. On the other hand, the production of biodegradable bioplastics (BBPs) has been gradually increasing, as they are considered as promising alternatives to common petrochemistry-based polymers. In 2018, over 2 million MTs of BBPs was produced worldwide with the major BBP types including poly(lactic acid) (PLA, 25\%), poly(butylene succinate) (PBS, 11\%), poly(butylene adipate terephthalate) (PBAT, $\sim 12 \%$ ), polyhydroxyalkanoates (PHA, $6 \%$ ), and starch blends ( 44\%) [49]. The number of scientific studies focused on BBPs alone has been rapidly increasing with almost 18 000 publications in PubMed as of March 2021. However, BBPs polymers are recalcitrant in the marine environment, as exemplified by Napper and Thompson [51] and represent an emerging group of pollutants and, at the same time, a new substratum for microbial colonization. Recent studies have showed that the current mass of ocean plastic is in the concentration range from between $0.1-1.0$ particles $\mathrm{m}^{-3}$ in the water column, and from $10^{3}-$ $10^{4}$ particles $\mathrm{m}^{-3}$ in sediments [52] and only $1 \%$ plastics entering the marine environment are observed floating at sea $\left[44^{\circ}, 53\right]$. This observation is quite surprising, considering the fact that over $65.5 \%$ of the world's plastic is 


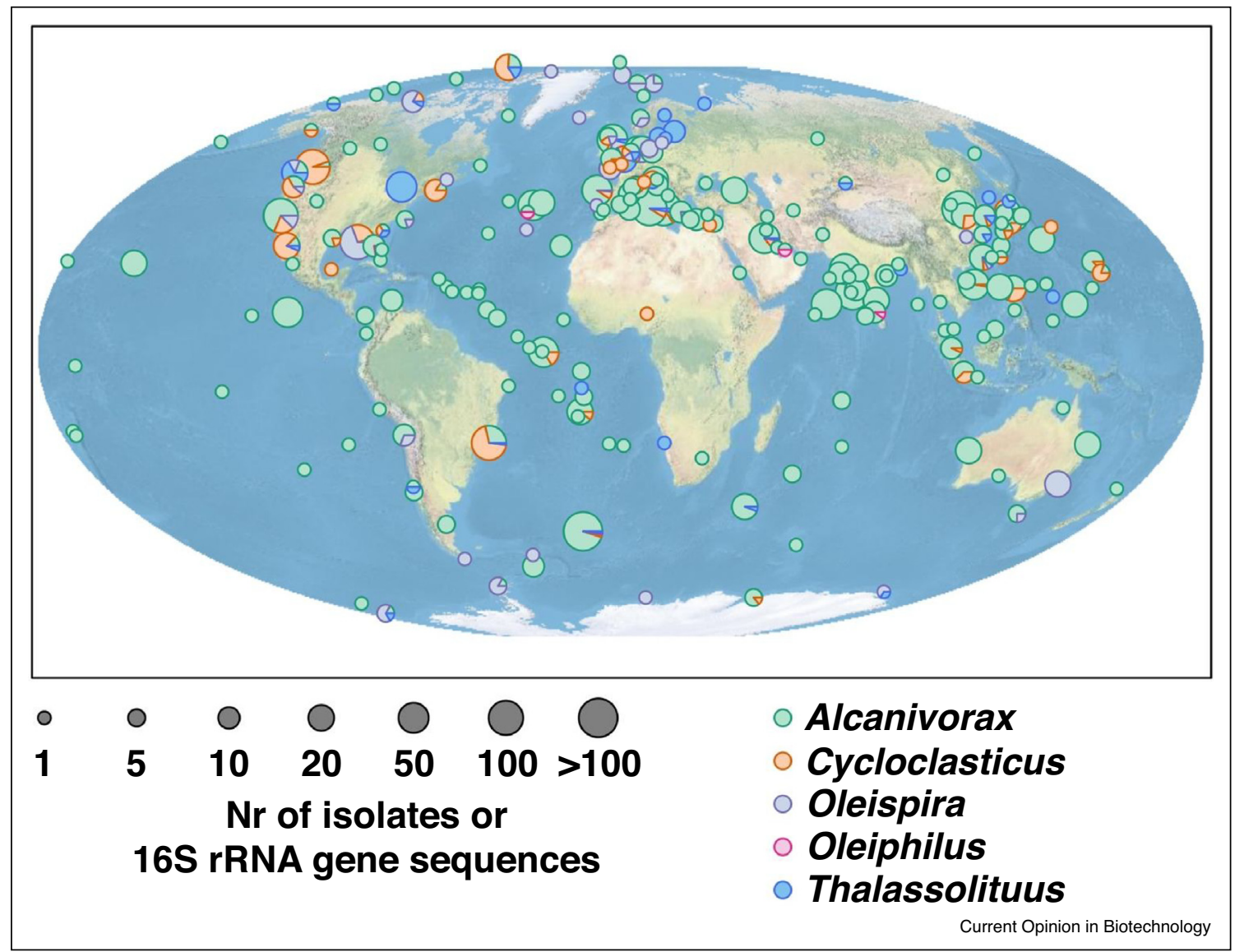

World map showing the distribution of the most prominent recognized genera that contain OHCB.

All available 16S rRNA gene sequences among GeneBank and SILVA databases with tagged coordinates have been used in the figure. When coordinates were not available, the location was approximately estimated, whenever possible. Figure was developed under $\mathrm{R}$ programming environment, using packages OpenStreetMap [28].

represented by lightweight polymers with a lower density than seawater [54].

The interest to marine plastisphere has recently stimulated numerous studies, which generated a breadth of data $\left[43,55^{\circ}, 56\right]$. Similar to the biofouling that occurs with any inert solid material entering the sea, the plastisphere develops rapidly on the surface of plastic debris when nutrients, carbon sources and energy are available. These determinants, as well as salinity, temperature and solar irradiation, are more likely to influence the development of a particular plastisphere [44 ${ }^{\bullet}$, which may significantly differ in microbial composition compared to free-living or particle-associated microbial populations in the surrounding water [57]. In addition, the type, size and status of the plastic itself (e.g. virgin or weathered) also affects the formation of the plastisphere, composition of which is to some extent characteristic for particular type of plastic $\left[58^{\bullet \bullet}, 59,60\right]$.
Given that common plastics are derived from fossil fuels, and especially, when oligomers and plastic additives (plasticizers) are available as a source of carbon and energy, one would expect that plastisphere should be enriched with OHCBs. The high hydrophobicity of petro-sourced polyolefins (PE, PP and PS) as well as PET, PVG, and PUR creates a strong interface when these materials are immersed in seawater, hindering attachment of the majority of planktonic hydrophilic microbiota. However, these surfaces can be quickly covered by marine microorganisms, possessing hydrophobic outer membrane. Worth to mention, the regulation of the hydrophobicity of outer membranes from neat and hydrophilic to indented and hydrophobic has been documented in a number of studies on marine OHCBs [9,61-64]. Following these expectations, we have attempted to validate the role of OHCBs in light of their abilities to both primary colonization (pioneering) and decomposition, at least partially, different types of marine plastic 
debris. A more targeted objective was to elucidate the specific role of OHCBs in the enzymatic (hydrolytic or redox) modification of the original polymer structure.

\section{Marine OHCBs play important role in primo- colonization of plastic}

Although there are many studies on the microbial composition of plastic biofilms, few studies have been devoted to detailed analysis of the successive phases of plastisphere's development $\left[55^{\circ}, 56\right]$. Like biofouling $[65,66]$, this process can be divided into three sequential events: (i) 'primo-colonization' phase, which implies the colonization of pioneer bacteria on the plastic surface, which form the first layer of the original biofilm; (ii) a 'growth phase' that promotes irreversible attachment through formation of extracellular matrix such as pili, adhesion proteins and exopolymeric substrate matrix (EPS) produced by both primary and secondary species; (iii) the 'maturation phase' occurs through diverse, competitive or synergistic interactions between cells with further recruitment or loss of species [59,67]. The role of OHCBs as key colonizers was first demonstrated by investigating the different phases of the colonization of polyolefin-based plastics, namely virgin low-density polyethylene (LDPE), PE with prooxidant (OXO), and artificially aged OXO (AA-OXO) [59]. Succession of plastisphere formed on plastic pieces was monitored for 45 days, with all three developmental phases observed. Notably, OHCBs belonging to genera Alcanivorax, Oleiphilus and Thalassolituus were especially abundant in the plastisphere during the primo-colonization phase and tended to decrease thereafter [59]. It is very likely, that LDPE attracts marine OHCBs independently of its status, since primo-colonization by these organisms was also observed on the weathered LDPE [68]. Similar to the research's data of Dussud et al. [59], the enrichment of a prominent OHCB, Oleiphilus messinensis, on both nonweathered and weathered LDPE only occurred at early stages of colonization (i.e. after two days of incubation in coastal marine water [Mallorca, Spain]; where they represented $3.7 \%$ and $5.8 \%$ of relative abundance, respectively, versus $0.6 \%$ on glass controls) [69]. To some extent, a similar observation was obtained during colonization experiments conducted with virgin high-density polyethylene (HDPE) microbeads $\left(1-4 \mu \mathrm{m} ; 0.96 \mathrm{~g} \mathrm{~cm}^{-3}\right)$ [66]. Incubation of seawater with HDPE for 108 hours stimulated the activity and enrichment of six OTUs, two of which were closely related to OHCBs of the genera Alcanivorax and Oleispira. The authors hypothesized that, due to an increase in oxygen consumption during incubation with HDPE as compared to control, these specific organisms were uniquely adapted to use organic carbon from virgin HDPE microbeads, likely plastic additives and/or plasticizers, as carbon and energy sources, pointing at their potential for the bioremediation of this type of plastic [69]. The plastisphere succession studied during colonization of three types of polyethylene terephthalate (virgin and weathered PET power [particles $<300 \mu \mathrm{m}$ ] and amorphous PET films [250 $\mu \mathrm{m}$ thickness]) for 42 days led to slightly different results [59]. In more details, members of Piscirickettsiaceae, the family accomodating the genus Cycloclasticus, were found in significant numbers (relative abundance 4.35\%) during all phases of plastisphere development on all type of plastic studied. Two different amplified sequence variants (ASV), ASV8 and ASV15 affiliated to Alcanivoraceae reached their maximum abundance of $15 \%$ and $2.35 \%$, respectively, but at later stages of the plastisphere formation. Notably, while ASV8 was visualized only on virgin PET powder and amorphous PET film, ASV15 was found to grow on all type of plastic studied. The joint participation of Alcanivorax and Cycloclasticus species in formation of a mature biofilm on the surface of PET films was confirmed in a separated study of Denaro et al. [70]. Interestingly, ATR-FTIR and SEM analyses revealed that most significant alterations (formation of small cracks and cavities) of the surface of PET films was mainly caused by the bacterial consortia enriched on either tetradecane or diesel [70].

\section{Plastic-degrading enzymes from OHCB}

As indicated above, marine OHCBs are likely to survive in pristine environments through the use of alkanes secreted either by marine cyanobacteria $\left[33,34^{\bullet}, 35^{\bullet \bullet}\right]$ or other eukaryotic primary producers [71,72]. Additionally, they appear to have a strong hydrolytic capacity towards aliphatic polyesters, both naturally occurring (e.g. polyhydroxyalkanoates [PHA]) and industrially produced (e. g. polybutylene succinate [PBS], polycaprolactone [PCL], polyethylene succinate [PES] and polylactic acid [PLA]) $\left[73,74,75^{\circ}\right]$. Nowadays these aliphatic polyesters, referred above as BBPs, still account for a small fraction of the global polymer market, but fortunately, consumer demand for these 'green' alternatives to traditional non-biodegradable petro-based materials is steadily growing $[73,74]$. Although the molecular mechanisms underlying the ability of OHCB strains to degrade such polyesters are currently unknown, genomes of OHCBs encode a large array of enzyme candidates that potentially can be active on BBPs. Indeed, numerous enzymes from Alcanivorax, Oleispira, and Cycloclasticus spp., either cloned from their genomes or recovered from metagenomic DNA fragments in crude oil enrichments and attributed to these organisms, were active on polyesters, including PLA, PBS, PHB and PET oligomers $\left[74,75^{\circ}, 76,77,78^{\circ}\right.$, $\left.79^{\circ}, 80,81^{\circ}, 82^{\circ}\right]$. In particular, Tchigvintsev et al. $\left[79^{\circ}\right]$ and Hajighasemi et al. [80] reported three ester hydrolases from the crude oil-seawater enrichments-derived metagenome, two of which were $100 \%$ identical to proteins encoded by A. borkumensis SK2 $2^{\mathrm{T}}$ genome, one of which, $\mathrm{ABO} 2449$, was hydrolyzing poly-(DL-lactic acid) polyesters. Notably, this activity of ABO2449 was found in both emulsified and solid PLA, with the capacity to degrade solid material being of high industrial interest. This polyester hydrolase had a highest activity at $30-37^{\circ} \mathrm{C}$ 


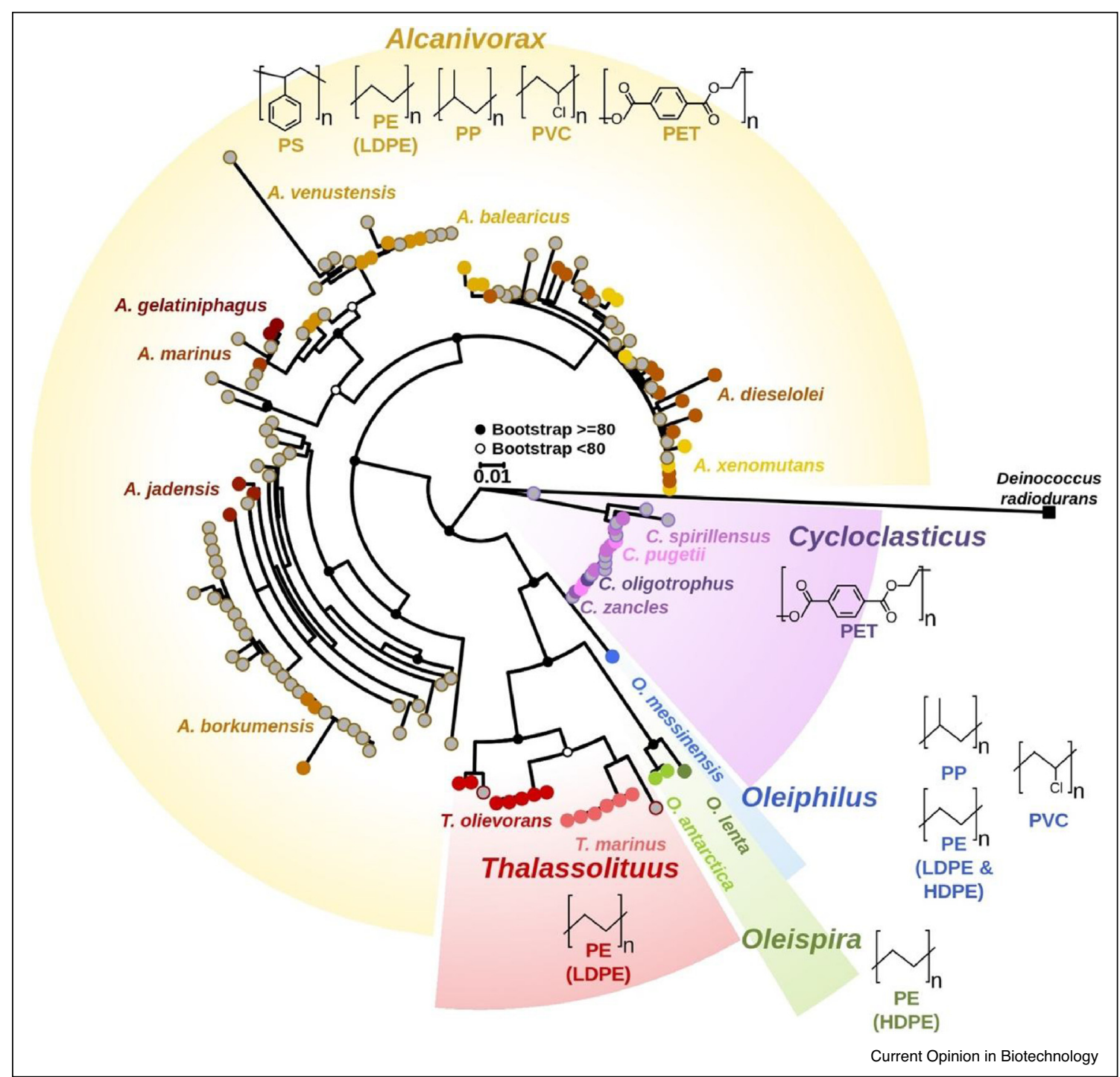

The SILVA-based tree of most prominent OHCB in marine plastisphere possessing the potential to both colonize and degrade plastics. Phylogenetic tree is based on an alignment of 1303 positions developed using Mafft [89] and trimmed using trimal [90]. From there, tree was calculated following a GTR model by Maximum likelihood method with bootstrapping of 1000 replicates. Calculations and drawing of the figure have been performed using $R$ programming environment [91] using package ape [92]. Branches belonging to unspecific species are filled on grey color. In case of evidences for the degradation of plastic polymers, these are shown next to each genus. Deinococcus radiodurans (AF289089) has been used as outgroup.

and retained $32 \%$ of the maximum activity at $4^{\circ} \mathrm{C}$, suggesting that its cold-adapted nature [83]. Search for novel and highly active polyesterases from marine metagenomes has led to the discovery of the esterase GEN0105, which hydrolyzes PCL, PLA as well as bis(benzoyloxyethyl)-terephthalate $\left[81^{\circ}\right]$. Phylogenetic analysis showed that this Family IV polyesterase, was closely related to the alpha/beta fold hydrolases CUR46463 and WP_055099617 from Alcanivorax xenomutans. The recent study on Alcanivorax sp. 24 isolated from marine plastic debris, which is able to degrade BBP polyesters (PBS,
PCL, PES and PHA), has also demonstrated its capacity of bis(2-hydroxyethyl)-terephthalate (BHET) degradation. Further analysis of abundantly secreted ALC24_4107 depolymerase revealed its promiscuous hydrolytic activity towards aliphatic polyesters, which makes it possible to biodegrade both natural and synthetic polyester plastics of anthropogenic origin [75 $]$.

As pointed out elsewhere, many polyesters of an unnatural origin exhibit a low bioavailability and are exposed to the microorganisms in their natural environment for a 
limited period of time, which may be a reason why the evolution of enzymatic pathways for plastic degradation in situ is a relatively slow process $\left[44^{\circ}, 84\right]$. Accordingly, the ubiquity of polyester-utilizing enzymes, for example, homologs of PETase from Idionella $\left[8^{\circ \bullet}\right]$, in marine bacteria and their communities, is correspondingly low, as reflected by the sequencing data analysis $\left[86^{\circ}, 87\right]$. However, it is also known that some families of esterases exhibit an enormous substrate promiscuity and some can utilize, for example, 74 from 96 natural and synthetic ester substrates tested $\left[8^{\circ}{ }^{\circ}\right.$ ]. This also suggests that predictions of enzymatic activities from genomic data may overlook enzymes that are readily available in nature and capable of polyester degradation and points at importance of functional enzyme discovery and experimental activity validation, for example, proteins with domains of unknown function (DUF) or 'unknowns'.

\section{Conclusion and outlook}

The situation with the biodegradation of both natural and synthetic polyesters looks more optimistic compared to the bioconversion of non-hydrolysable polyolefins of petrochemical origin, such as polyethylene, polypropylene and polystyrene, which is hampered by the high redox potential required to cleave carbon-carbon bonds. However, the ability of OHCB to form thick biofilms specifically on LDPE, and break down this petroleum-based plastic has recently been demonstrated [60]. As mentioned above, bacteria of the family Alcanivoraxaceae are also able to colonize the HDPE microbeads and, probably, use organic carbon from this type of plastic [69] (Figure 2).

Only four types of enzymes (manganese and soybean peroxidases, laccase and alkane hydroxylases [monooxygenases]) have exhibited the PE degradation activities [93]. Since all OHCB possess a large repertoire of enzymes of the latter type $(\mathrm{AlkB}, \mathrm{AlmA}$ and P450 monoxygenases), their participation in degradation of low molecular-weight $\mathrm{PE}$ in marine environment could be foreseen. It is worth to mention that a recent quantum mechanics study predicting the catalytic mechanism of P450 monooxygenase suggested that oxygenase-induced free radical transitions may cause the cleavage of the carbon-carbon backbone of polyolefins (PE and PS) [94].While these studies suggest a fundamental possibility that the biodegradation processes of $\mathrm{PE}$ or PS, which is at least partially performed by OHCB, are feasible in principle (Figure 2), more effort is needed to characterize biochemical functions of corresponding enzyme candidates to help predicting the plastics biodegradation pathways and enable the engineering of microbial catalysts for plastics biodegradation or recycling $\left[95^{\circ}\right]$.

With the prevalence of plastic marine debris and the continued growth in plastic production, the impact of plastic on marine ecosystems is likely to intensify.
Currently, the possibilities of microbial communities developing on the surface of plastic (marine plastisphere) to change the structure and depolymerize both natural and synthetic polyesters are being actively studied. We expect that OHCBs as part of the plastisphere - by accelerating the characterization of their genetic circuits and repertoires - to make a significant contribution to the biodegradation of plastics in the marine ecosystems.

\section{Conflict of interest statement}

Nothing declared.

\section{CRediT authorship contribution statement}

Michail M Yakimov: Conceptualization, Methodology, Writing - original draft. Rafael Bargiela: Software, Data curation, Visualization. Peter N Golyshin: Conceptualization, Writing - review \& editing.

\section{Acknowledgements}

This work was supported by research funds from the Italian Ministry of University and Research (MUR), PRIN 2017, code: 201728ZA49_002 and by the European Commission's Horizon Work Program H2020-FNR-2020 under FUTURENZYME Project Contract (101000327). RB and PNG acknowledge the support of the Centre for Environmental Biotechnology Project co-funded by the European Regional Development Fund (ERDF) through the Welsh Government. PNG acknowledges the support of the project 'Plastic Vectors' funded by the Natural Environment Research Council UK (NERC), Grant No. NE/S004548/1.

\section{References and recommended reading}

Papers of particular interest, published within the period of review, have been highlighted as:

- of special interest

•. of outstanding interest

1. Yakimov MM, Timmis KN, Golyshin PN: Obligate oil-degrading -. marine bacteria. Curr Opin Biotechnol 2007, 18:257-266

One of the first reviews describing the physiologically novel group of hydrocarbon-degrading marine bacteria.

2. van Beilen JB et al.: Analysis of Pseudomonas putida alkanedegradation gene clusters and flanking insertion sequences: evolution and regulation of the alk genes. Microbiology (Reading) 2001, 147:1621-1630 http://dx.doi.org/10.1099/ 00221287-147-6-1621.

3. Williams PA, Murray K: Metabolism of benzoate and the methylbenzoates by Pseudomonas putida (arvilla) mt-2: evidence for the existence of a TOL plasmid. J Bacteriol 1974 120:416-423 http://dx.doi.org/10.1128/jb.120.1.416-423.

4. Nie $\mathrm{Y}$ et al.: Diverse alkane hydroxylase genes in microorganisms and environments. Sci Rep 2014, 4:4968 http:// dx.doi.org/10.1038/srep04968.

5. Engelhardt MA, Daly K, Swannell RPJ, Head IM: Isolation and characterization of a novel hydrocarbon-degrading, Grampositive bacterium, isolated from intertidal beach sediment, and description of Planococcus alkanoclasticus sp. nov. J Appl Microbiol 2001, 90:237-247.

6. Gutierrez T, Nichols PD, Whitman WB, Aitken MD: Porticoccus

- hydrocarbonoclasticus sp. nov., an aromatic hydrocarbondegrading bacterium identified in laboratory cultures of marine phytoplankton. Appl Environ Microbiol 2012, 78:628-637

An important report introducing a novel member of OHCB group.

7. Gutierrez T, Green DH, Whitman WB, Nichols PD, Semple KT,

- $\quad$ Aitken MD: Algiphilus aromaticivorans gen. nov., sp. nov., an aromatic hydrocarbon-degrading bacterium isolated from a culture of the marine dinoflagellate Lingulodinium polyedrum, 
and proposal of Algiphilaceae fam. nov. Int J Syst Evol Microbiol 2012, 62:2743-2749

An important report on a novel member of OHCB group.

8. Gutierrez T, Green DH, Nichols PD, Whitman WB, Semple KT

- $\quad$ Aitken MD: Polycyclovorans algicola gen. nov., sp. nov., an aromatic-hydrocarbon-degrading marine bacterium found associated with laboratory cultures of marine phytoplankton. Appl Environ Microbiol 2013, 79:205-214

An important report describing a novel member of OHCB group.

9. Yakimov MM, Golyshin PN, Lang S, Moore ER, Abraham WR, Lünsdorf H, Timmis KN: Alcanivorax borkumensis gen. nov., sp. nov., a new, hydrocarbon-degrading and surfactant-

producing marine bacterium. Int J Syst Bacteriol 1998, 48:339348.

10. Hedlund BP, Geiselbrecht AD, Bair TJ, Staley JT: Polycyclic aromatic hydrocarbon degradation by a new marine bacterium, Neptunomonas naphthovorans gen. nov., sp. nov. Appl Environ Microbiol 1999, 65:251-259.

11. Teramoto $M$, Ohuchi $M$, Hatmanti $A$, Darmayati $Y$, Widyastuti $Y$, Harayama S, Fukunaga Y: Oleibacter marinus gen. nov., sp. nov., a bacterium that degrades petroleum aliphatic hydrocarbons in a tropical marine environment. Int J Syst Evol Microbiol 2011, 61:375-380.

12. Golyshin PN, Chernikova TN, Abraham WR, Lunsdorf $\mathrm{H}$, Timmis KN, Yakimov MM: Oleiphilaceae fam. nov., to include Oleiphilus messinensis gen. nov., sp. nov., a novel marine bacterium that obligately utilizes hydrocarbons. Int J Syst Evol Microbiol 2002, 52:901-911.

13. Yakimov MM, Giuliano L, Gentile G, Crisafi E, Chernikova TN, Abraham WR, Lünsdorf H, Timmis KN, Golyshin PN: Oleispira antarctica gen. nov., sp. nov., a novel hydrocarbonoclastic marine bacterium isolated from Antarctic coastal sea water. Int J Syst Evol Microbiol 2003, 53:779-785.

14. Yakimov MM, Giuliano L, Denaro R, Crisafi E, Chernikova TN, Abraham WR, Luensdorf H, Timmis KN, Golyshin PN: Thalassolituus oleivorans gen. nov., sp. nov., a novel marine bacterium that obligately utilizes hydrocarbons. Int J Syst Evol Microbiol 2004, 54:141-148.

15. Dyksterhouse SE, Gray JP, Herwig RP, Lara JC, Staley JT Cycloclasticus pugetii gen. nov., sp. nov., an aromatic hydrocarbon- degrading bacterium from marine sediments. Int J Syst Bacteriol 1995, 45:116-123.

16. McGenity TJ, Folwell BD, McKew BA, Sanni GO: Marine crude-oi biodegradation: a central role for interspecies interactions. Aquat Biosyst 2012, 8:10.

17. Gutierrez T: Marine, aerobic hydrocarbon-degrading gammaproteobacteria: overview. In Taxonomy, Genomics and Ecophysiology of Hydrocarbon-Degrading Microbes. Edited by McGenity TJ. Cham: Springer; 2017:1-10.

18. Gutierrez T: Aerobic hydrocarbon-degrading Gammaproteobacteria: Porticoccus, In Taxonomy Genomics and Ecophysiology of Hydrocarbon-Degrading Microbes. Edited by McGenity TJ. Cham: Springer; 2019:181-189.

19. Yakimov MM, Golyshin PN, Crisafi F, Denaro R, Giuliano L: Marine, aerobic hydrocarbon-degrading Gammaproteobacteria: the family Alcanivoracaceae. In Taxonomy, Genomics and Ecophysiology of HydrocarbonDegrading Microbes. Edited by McGenity TJ. Cham: Springer; 2019:167-179.

20. Hassan HA, Rizk NMH, Hefnawy MA, Awad AM: Isolation and characterization of halophilic aromatic and chloroaromatic degrader from Wadi El-Natrun Soda lakes. Life Sci J 2012, 9:1565-1570

21. Rubin-Blum M, Antony CP, Borowski C, Sayavedra L, Pape T, Sahling H, Bohrmann G, Kleiner M, Redmond MC, Valentine DL, Dubilier N: Short-chain alkanes fuel mussel and sponge Cycloclasticus symbionts from deep-sea gas and oil seeps. Nat Microbiol 2017, 2:17093.

22. Valentine DL, Kessler JD, Redmond MC, Mendes SD, Heintz MB, Farwell C, Hu L, Kinnaman FS, Yvon-Lewis S, Du M et al.: Propane respiration jump starts microbial response to a deep oil spill. Science 2010, 330:208-211.

23. Gutierrez T, Singleton DR, Berry D, Yang T, Aitken MD, Teske A: Hydrocarbon-degrading bacteria enriched by the Deepwater Horizon oil spill identified by cultivation and DNA-SIP. ISME J 2013, 7:2091-2104.

24. Kleindienst S, Grim S, Sogin M, Bracco A, Crespo-Medina M, Joye SB: Diverse, rare microbial taxa responded to the Deepwater Horizon deep-sea hydrocarbon plume. ISME J 2016, 10:400-415.

25. Dombrowski N, Donaho J, Gutierrez T, Seitz KW, Teske AP, Baker BJ: Reconstructing metabolic pathways of hydrocarbon-degrading bacteria from the Deepwater Horizon oil spill. Nat Microbiol 2016, 1:16057.

26. Yang T, Speare K, McKay L, MacGregor BJ, Joye SB, Teske A: Distinct bacterial communities in surficial seafloor sediments following the 2010 Deepwater Horizon blowout. Front Microbiol 2016, 7:1384.

27. Gutierrez T, Morris G, Ellis D, Bowler B, Jones M, Salek K, Mulloy B, Teske A: Hydrocarbon-degradation and MOSformation capabilities of the dominant bacteria enriched in sea surface oil slicks during the Deepwater Horizon oil spill. Mar Pollut Bull 2018, 135:205-215.

28. Padgham M, Rudis B, Lovelace R, Salmon M: osmdata. J Open Source Softw 2017, 2:315

29. Gutierrez T: Occurrence and roles of the obligate hydrocarbonoclastic bacteria in the ocean when there is no obvious hydrocarbon contamination. In Taxonomy, Genomics and Ecophysiology of Hydrocarbon-Degrading Microbes. Edited by McGenity TJ. Cham: Springer; 2019.

30. Han J, McCarthy ED, Hoeven WV, Calvin M, Bradley WH: Organic geochemical studies II. A preliminary report on the distribution of aliphatic hydrocarbons in algae, in bacteria, and in recent lake sediment. Proc Natl Acad Sci U S A 1968, 59:29-33.

31. Han J, Calvin M: Hydrocarbon distribution of algae and

-. bacteria, and microbiological activity in sediments. Proc Nat Acad Sci U S A 1969, 64:436-443

One of the first reports on very significant yields of hydrocarbons (primarily, medium-chain alkanes) production in cyanobacteria ('blue-green algae').

32. Schirmer A, Rude MA, Li X, Popova E, del Cardayre SB: Microbial - biosynthesis of alkanes. Science 2010, 329:559-562

An important report on pathways for cyanobacterial biosynthesis of alkanes.

33. Coates RC, Podell S, Korobeynikov A, Lapidus A, Pevzner P: Characterization of cyanobacterial hydrocarbon composition and distribution of biosynthetic pathways. PLoS One 2014, 9:85140.

34. Lea-Smith DJ, Biller SJ, Davey MP, Cotton CAR, Sepulveda BMP,

- Turchyn AV, Scanlan DJ, Smith AG, Chisholm SW, Howe CJ: Contribution of cyanobacterial alkane production to the ocean hydrocarbon cycle. Proc Natl Acad Sci U S A 2015, 112:1359113596

A series of laboratory microcosm experiments with alkane producing cyanobacteria and $A$. borkumensis SK2 suggest the OHCB can sustain its growth on pentadecane from photosynthetic alkane producer. It was predicted that the short-term microbial hydrocarbon loop may globally be of a great scale.

35. Love CR, Arrington EC, Gosselin KM, Reddy CM, Van Mooy BAS,

- Nelson RK, Valentine DL: Microbial production and consumption of hydrocarbons in the global ocean. Nat Microbio 2021, 6:489-498

In situ hydrocarbon production measurements and scale-up modelling suggested the scale of the 'short-term' (or 'cryptic') hydrocarbon cycle outweighs, at least hundredfold, the petroleum input into the global ocean.

36. Harada N, Hirose Y, Chihong S, Kurita H, Sato M, Onodera J, Murata K, Itoh F: A novel characteristic of a phytoplankton as a potential source of straight-chain alkanes. Sci Rep 2021, 11:14190. 
37. Green DH, Llewellyn LE, Negri AP, Blackburn SI, Bolch CJS: Phylogenetic and functional diversity of the cultivable bacterial community associated with the paralytic shellfish poisoning dinoflagellate Gymnodinium catenatum. FEMS Microbiol Ecol 2004, 47:345-357.

38. Green DH, Bowman JP, Smith EA, Gutierrez T, Bolch CJS: Marinobacter algicola $s p$. nov., isolated from laboratory cultures of paralytic shellfish toxin-producing dinoflagellates. Int J Syst Evol Microbiol 2006, 56:523-527.

39. Green DH, Echavarri-Bravo V, Brennan D, Hart MC: Bacterial diversity associated with the coccolithophorid algae Emiliania huxleyi and Coccolithus pelagicus $f$. braarudii. Biomed Res Int 2015:194540.

40. Chernikova TN, Bargiela R, Toshchakov SV, Shivaraman V, Lunev EA, Yakimov MM, Thomas DN, Golyshin PN: Hydrocarbondegrading bacteria Alcanivorax and Marinobacter associated with microalgae Pavlova lutheri and Nannochloropsis oculata. Front Microbiol 2020, 11:572931.

41. Thompson HF, Summers S, Yuecel R, Gutierrez T: Hydrocarbondegrading bacteria found tightly associated with the $50-70 \mu \mathrm{m}$ cell-size population of eukaryotic phytoplankton in surface waters of a northeast Atlantic Region. Microorganisms 2020, 8:1955.

42. Amaral-Zettler LA, Zettler ER, Slikas B, Boyd GD, Melvin DW, Morrall CE, Proskurowski G, Mincer TJ: The biogeography of the Plastisphere: implications for policy. Front Ecol Environ 2015, 13:541-546.

43. Amaral-Zettler LA, Zettler ER, Mincer TJ: Ecology of the Plastisphere. Nat Rev Microbiol 2020, 18:139-151.

44. Oberbeckmann S, Labrenz M: Marine microbial assemblages

- on microplastics: diversity, adaptation, and role in degradation. Annu Rev Mar Sci 2020, 12:1-24

A comprehensive critical analysis of a multitude of studies on marine 'Plastisphere'.

45. Ogonowski M, Motiei A, Ininbergs K, Hell E, Gerdes Z, Udekwu KI, Bacsik Z, Gorokhova E: Evidence for selective bacterial community structuring on microplastics. Environ Microbiol 2018, 20:2796-2808.

46. Reisser J, Shaw J, Hallegraeff G, Proietti M, Barnes DKA, Thums M, Wilcox C, Hardesty BD, Pattiaratchi C: Millimeter-sized marine plastics: a new pelagic habitat for microorganisms and invertebrates. PLoS One 2014, 9:e100289.

47. Rummel CD, Jahnke A, Gorokhova E, Kühnel D, SchmittJansen M: The Impacts of biofilm formation on the fate and potential effects of microplastic in the aquatic environment. Environ Sci Technol Lett 2017, 4:258-267.

48. Jambeck J, Geyer R, Wilcox C, Siegler T, Perryman M, Andrady A, Narayan R, Law K: Marine pollution. Plastic waste inputs from land into the ocean. Science 2015, 347:768-771.

49. Plastics Europe: Plastics - The Facts 2018: An Analysis of European Plastics Production, Demand and Waste Data (EB/OL). . URL: 2018 http://www.plasticseurope.org/.

50. Galgani L, Loiselle SA: Plastic pollution impacts on marine carbon biogeochemistry. Environ Pollut 2021, 268:115598 http:// dx.doi.org/10.1016/j.envpol.2020.115598.

51. Napper IE, Thompson RC: Environmental deterioration of biodegradable, oxo-biodegradable, compostable, and conventional plastic carrier bags in the sea, soil, and open-air over a 3-year period. Environ Sci Technol 2019, 53:4775-4783.

52. Erni-Cassola G, Zadjelovic V, Gibson MI, Christie-Oleza JA: Distribution of plastic polymer types in the marine environment; a meta-analysis. J Hazard Mater 2019, 369:691698.

53. Van Sebille E, Wilcox C, Lebreton L, Maximenko N, Hardesty BD, Van Franeker JA, Eriksen M, Siegel D, Galgani F, Law KLA: Global inventory of small floating plastic debris. Environ Res Lett 2015, 10:1-11.

54. Geyer R, Jambeck JR, Law KL: Production, use, and fate of all plastics ever made. Sci Adv 2017, 3:e1700782.
55. Wright RJ, Erni-Cassola G, Zadjelovic V, Latva M, Christie-Oleza J:

- Marine plastic debris - a new surface for microbial colonization. Environ Sci Technol 2020, 54:11657-11672

A highly recommended critical overview of various aspects of colonization and degradation of plastics in marine environments.

56. Wright RJ, Langille MGI, Walker TR: Food or just a free ride? A meta-analysis reveals the global diversity of the Plastisphere. ISME J 2021, 15:789-806.

57. Yang Y, Liu W, Zhang Z, Grossart H-P, Gadd GM: Microplastics provide new microbial niches in aquatic environments. Appl Microbiol Biotechnol 2020, 104:6501-6651.

58. Zettler ER, Mincer TJ, Amaral-Zettler LA: Life in the

-• "plastisphere": microbial communities on plastic marine debris. Environ Sci Technol 2013, 47:7137-7146

An important study, which conceptualized the plastic surface as a distinct environment for microbial colonization.

59. Dussud C, Hudec C, George M, Fabre P, Higgs P, Bruzaud S, Delort A-M, Eyheraguibel B, Meistertzheim A-L, Jacquin J et al.: Colonization of non-biodegradable and biodegradable plastics by marine microorganisms. Front Microbiol 2018, 9:1571.

60. Delacuvellerie A, Cyriaque V, Gobert S, Benali S, Wattiez R: The plastisphere in marine ecosystem hosts potential specific microbial degraders including Alcanivorax borkumensis as a key player for the low-density polyethylene degradation. $J$ Hazard Mat 2019, 280:1-120899.

61. Abraham WR, Meyer $\mathrm{H}$, Yakimov M: Novel glycine containing glucolipids from the alkane using bacterium Alcanivorax borkumensis. Biochim Biophys 1998, 1393:57-62 http://dx.doi. org/10.1016/S0005-2760(98)00058-7.

62. Manilla-Pérez E, Lange AB, Hetzler S, Steinbüchel A: Occurrence, production, and export of lipophilic compounds by hydrocarbonoclastic marine bacteria and their potential use to produce bulk chemicals from hydrocarbons. Appl Microbiol Biotechnol 2010, 86:1693-1706.

63. Naether DJ, Slawtschew S, Stasik S, Engel M, Olzog M, Wick LY: Adaptation of the hydrocarbonoclastic bacterium Alcanivorax borkumensis SK2 to alkanes and toxic organic compounds: a physiological and transcriptomic approach. Appl Environ Microbiol 2013, 79:4282-4293.

64. Barbato M, Scoma A, Mapelli F, De Smet R, Banat IM, Daffonchio D, Boon N, Borin S: Hydrocarbonoclastic Alcanivorax isolates exhibit different physiological and expression responses to $\mathbf{n}$-dodecane. Front Microbiol 2016, 7:2056.

65. Dang H, Lovell CR: Bacterial primary colonization and early succession on surfaces in marine waters as determined by amplified rRNA gene restriction analysis and sequence analysis of 16S rRNA genes. Appl Environ Microbiol 2020, 66:467-475.

66. Salta M, Wharton JA, Blache Y, Stokes KR, Briand JF: Marine biofilms on artificial surfaces: structure and dynamics. Environ Microbiol 2013, 15:2879-2893.

67. Lorite GS, Rodrigues CM, De Souza AA, Kranz C, Mizaikoff B, Cotta MA: The role of conditioning film formation and surface chemical changes on Xylella fastidiosa adhesion and biofilm evolution. J Colloid Interface Sci 2011, 359:289-295.

68. Erni-Cassola G, Wright RJ, Gibson MI, Christie-Oleza JA: Early colonization of weathered polyethylene by distinct bacteria in marine coastal seawater. Microb Ecol 2020, 79:517-526.

69. Girard EB, Kaliwoda M, Schmahl WW, Wörheide G, Orsi WD: Biodegradation of textile waste by marine bacterial communities enhanced by light. Environ Microbiol Rep 2021, 12:406-418.

70. Denaro R, Aulenta F, Crisafi F, Di Pippo F, Cruz Viggi C, Matturro B, Tomei P, Smedile F, Martinelli A, Di Lisio V et al.: Marine hydrocarbon-degrading bacteria breakdown poly(ethylene terephthalate) (PET). Sci Total Environ 2020, 749:141608.

71. Sorigué $D$, Legeret $B$, Cuine $S$, Morales $P$, Mirabella $B$, Guedeney G, Li-Beisson $\mathrm{Y}$, Jetter R, Peltier G, Beisson F: 
Microalgae synthesize hydrocarbons from long-chain fatty acids via a light-dependent pathway. Plant Physiol 2016 171:2393-2405.

72. Sorigué D, Légeret B, Cuiné S, Blangy S, Moulin S, Billon E, Richaud $P$, Brugière S, Couté $Y$, Nurizzo D et al.: An algal photoenzyme converts fatty acids to hydrocarbons. Science 2017, 357:903-907.

73. Sekiguchi T, Saika A, Nomura K, Watanabe T, Watanabe T, Fujimoto Y, Enoki M, Sato T, Kato C, Kanehiro H: Biodegradation of aliphatic polyesters soaked in deep seawaters and isolation of poly( $\varepsilon$-caprolactone)-degrading bacteria. Polym Degrad Stab 2011, 96:1397-1403.

74. Zadjelovic V, Gibson MI, Dorador C, Christie-Oleza JA: Genome of Alcanivorax sp. 24: a hydrocarbon degrading bacterium isolated from marine plastic debris. Mar Genomics 2019, 49:14.

75. Zadjelovic V, Chhun A, Quareshy M, Silvano E, Hernandez-

- Fernaud JR, Aguilo-Ferretjans MM, Bosch R, Dorador C, Gibson MI, Christie-Oleza JA: Beyond oil degradation: enzymatic potential of Alcanivorax to degrade natural and synthetic polyesters. Environ Microbiol 2020, 22:1356-1369

Alcanivorax sp. 24 isolated from marine plastic debris has a larger genome and a broader substrate spectrum than the 'classical' OHCB strain SK2; it encodes an array of enzymes active on a range of polyester substrates, including BBP.

76. Tokiwa Y, Calabia BP, Ugwu CU, Aiba S: Biodegradability of plastics. Int J Mol Sci 2009, 10:3722-3742.

77. Aeschelmann F, Carus M: Biobased building blocks and polymers in the world: capacities, production, and applications-status quo and trends towards 2020. Ind Biotechnol 2015, 11:154-159.

78. Kube M, Chernikova TN, Al-Ramahi Y, Beloqui A, Lopez-Cortez N,

•• Guazzaroni ME, Heipieper HJ, Klages S, Kotsyurbenko OR, Langer I et al.: Genome sequence and functional genomic analysis of the oil-degrading bacterium Oleispira antarctica. Nat Commun 2013, 4:2156

A comprehensive analysis of a cold-adapted OHCB important in deep cold and polar seas. Cold-adapted chaperonin interactome suggested proteins important for life in the cold. Dozens of enzymes (including carboxylestarases) have been cloned and characterized. Surprisingly, majority of proteins had mesophilic activity optima. The study has more than doubled the number of cold-adapted proteins in PDB.

79. Tchigvintsev A, Tran H, Popovic A, Kovacic F, Brown G, Flick R,

- Hajighasemi M, Egorova O, Somody JC, Tchigvintsev D et al:: The environment shapes microbial enzymes: five cold-active and salt-resistant carboxylesterases from marine metagenomes. Appl Microbiol Biotechnol 2015, 99:2165-2178

A number of esterases active on polyesters from crude oil enrichment metagenomes active on polyesters.

80. Hajighasemi M, Nocek BP, Tchigvintsev A, Brown G, Flick R, Xu X, Cui H, Hai T, Joachimiak A, Golyshin PN et al.: Biochemical and structural insights into enzymatic depolymerization of polylactic acid and other polyesters by microbial carboxylesterases. Biomacromolecules 2016, 17:2027-2039.

81. Hajighasemi M, Tchigvintsev A, Nocek B, Flick R, Popovic A, Hai T,

- Khusnutdinova AN, Brown G, Xu X, Cui H et al:: Screening and characterization of novel polyesterases from environmental metagenomes with high hydrolytic activity against synthetic polyesters. Environ Sci Technol 2018, 52:12388-12401

Esterases including those from OHCB genomes or crude oil-enriched metagenomes were active on polyesters, PLA, PCL, PBSA and 3PET. The latter substrate was converted by four enzymes from OHCB $A$. borkumensis SK2.

82. Popovic A, Hai T, Tchigvintsev A, Hajighasemi M, Nocek B,

- Khusnutdinova AN, Brown G, Glinos J, Flick R, Skarina T et al.: Activity screening of environmental metagenomic libraries reveals novel carboxylesterase families. Sci Rep 2017, 7:44103 Screening of $>1 \mathrm{M}$ metagenomic clones led to a full characterization of $>80$ esterases active on polyesters, for example, PLA and PCL. Study revealed active enzymes from new protein families, DUF3089 and 'unknown'. Both were derived from hydrocarbon-degrading microbial communities: from naphthalene-spiked sample enriched in Cycloclasticus sp. (Messina harbour) and from crude oil-grown biofilm from the hull of the tanker M/T Haven sunken in 1991 off Genoa.

83. Coscolín C, Bargiela R, Martínez-Martínez M, Alonso S, Bollinger A, Thies S, Chernikova TN, Hai T, Golyshina OV, Jaeger K-E et al:: Hydrocarbon-degrading microbes as sources of new biocatalysts. In Taxonomy, genomics and ecophysiology of hydrocarbon-degrading microbes. Edited by McGenity TJ. Cham: Springer; 2018:353-373 http://dx.doi.org/10.1007/978-3030-14796-9 13.

84. Krueger MC, Harms H, Schlosser D: Prospects for microbiological solutions to environmental pollution with plastics. Appl Microbiol Biotechnol 2015, 99:8857-8874.

85. Yoshida S, Hiraga K, Takehana T, Taniguchi I, Yamaji H, Maeda Y,

-• Toyohara K, Miyamoto K, Kimura Y, Oda K: A bacterium that degrades and assimilates poly(ethylene terephthalate). Science 2016, 351:1196-1199

A landmark discovery of a PET-mineralising bacterium Ideonella sakaiensis with the two key enzymes for hydrolysis of PET and the reaction intermediate, mono(2-hydroxyethyl) terephthalic acid to produce easily biodegradable ethylene glycol and terephtalic acid.

86. Danso D, Schmeisser C, Chow J, Zimmermann W, Wei R,

- Leggewie C, Li X, Hazen T, Streit WR: New insights into the function and global distribution of polyethylene terephthalate (PET)-degrading bacteria and enzymes in marine and terrestrial metagenomes. Appl Environ Microbiol 2018, 84: e02773-17

A global survey of marine and terrestrial metagenomes has identified \&800 enzyme candidates predicted to hydrolyse PET, few enzymes were expressed and their activities confirmed. One of characterised PETases was derived from the OHCB, Oleispira antarctica RB-8.

87. Danso D, Chow J, Streit WR: Plastics: environmental and biotechnological perspectives on microbial degradation. Appl Environ Microbiol 2019, 85:e01095-19.

88. Marti'nez-Marti'nez M, Coscoli'n C, Santiago G, Chow J,

- Stogios PJ, Bargiela R, Gertler C, Navarro-Ferna'ndez J, Bollinger A, Thies $S$ et al.: Determinants and prediction of esterase substrate promiscuity patterns. ACS Chem Biol 2018 , 13:225-234

Substrate profiling of approx. 150 carboxylesterases, including enzymes from OHCB, revealed a remarkable substrate promiscuity in enzymes of Family VI: some enzymes converted up to 74 of 96 tested ester substrates, including non-natural esters. Structural modelling suggested the 'active site effective volume' as a main predictive marker for substrate promiscuity.

89. Katoh K, Standley DM: MAFFT multiple sequence alignment software version 7: improvements in performance and usability. Mol Biol Evol 2013, 30:772-780.

90. Capella-Gutiérrez S, Silla-Martínez JM, Gabaldón T: trimAl: a tool for automated alignment trimming in large-scale phylogenetic analyses. Bioinformatics 2009, 25:1972-1973.

91. Team RDC: R: A Language and Environment for Statistical Computing. R Foundation for Statistical Computing; 2010.

92. Paradis E, Schliep K: ape 5.0: an environment for modern phylogenetics and evolutionary analyses in R. Bioinformatics 2019, 35:526-528.

93. Ru J, Huo Y, Yang Y: Microbial degradation and valorization of plastic wastes. Front Microbiol 2020, 11:442.

94. Xu J, Cui Z, Nie K, Cao H, Jiang M, Xu H, Tan T, Liu L: A quantum mechanism study of the cc bond cleavage to predict the biocatalytic polyethylene degradation. Front Microbiol 2019, 10:489.

95. Wei R, Tiso T, Bertling J, O'Connor K, Blank LM, Bornscheuer UT:

- Possibilities and limitations of biotechnological plastic degradation and recycling. Nat Catal 2020, 3:867-871

A very thorough overview about perspectives and challenges of biotech approaches to for plastic biodegradation and recycling. 